\title{
ANALISIS TERHADAP UNDANG UNDANG KETENAGAKERJAAN INDONESIA DALAM MENGHADAPI TANTANGAN REVOLUSI INDUSTRI 4.0
}

\author{
ANALYSIS OF THE INDONESIAN LABOR LAW \\ IN FACING THE CHALLENGES OF THE INDUSTRIAL REVOLUTION 4.0
}

\author{
Yeni Nuraeni \\ Pusat Penelitian dan Pengembangan, Kementerian Ketenagakerjaan RI \\ J1. Jendral Gatot Subroto Kav. 51, Jakarta Selatan, DKI Jakarta \\ yeninur@hotmail.com
}

\begin{abstract}
ABSTRAK
Indonesia memiliki sumber daya manusia yang berlimpah dari segi kuantitas, sehingga akan menjadi lahan yang sangat potensial bagi penerapan industri 4.0. Di era informasi digital selain akan membawa kemajuan bagi dunia industri, tetapi berpotensi juga akan memberikan masalah bagi hukum Ketenagakerjaan. Penelitian ini bertujuan untuk menganalisis masalah-masalah Ketenagakerjaan yang dapat terjadi sebagai akibat belum tersedia regulasi yang sesuai dengan kondisi di era revolusi industri 4.0. Metode penelitian yang digunakan adalah yuridis normatif dengan menggunakan pendekatan statute approach dan case approach. Hasil penelitian menunjukkan ada beberapa permasalahan yang sudah banyak terjadi dan akan terus berlanjut di Era Revolusi Industri 4.0 dan belum diatur regulasinya dalam UU No 13 tentang Ketenagakeraan dan aturan turunannnya. Masalah Ketenagakerjaan yang segera harus diatur regulasinya adalah hubungan industrial yang lebih bersifat pertemanan/partnership dibandingkan bersifat statis, employ cost yang pembayarannya lebih tergantung pada kesepakatan, tingkat keahlian dan hasil kerja, pengembangan kompetensi pekerja serta perlindungan pekerja terhadap pemutusan hubungan kerja yang memiliki kecenderungan akan terjadi secara besar-besaran. Revisi UU No 13 tahun 2003 harus dapat mengakomodir secara spesifik perubahan-perubahan yang terjadi dalam bidang Ketenagakerjaan seiring dengan Revolusi Industri 4.0.
\end{abstract}

Kata Kunci: Analisis Hukum Ketenagkerjaan; Revolusi Industri 4.0; Metode Yuridis Normatif

\begin{abstract}
Indonesia has abundant human resources in terms of quantity, so it will become a very potential land for the application of industry 4.0. In the digital information era, besides bringing progress to the industrial world, it also has the potential to create problems for labor law. This study aims to analyze labor problems that can occur as a result of the lack of regulations that are in accordance with the conditions in the era of industrial revolution 4.0. The research method used is normative juridical using a statute approach and case approach. The results of the study show that there have been several problems that have occurred and will continue in the Era of Industrial Revolution 4.0 and have not been regulated in Law No. 13 of 2003 and its derivative rules are concerning Manpower. Immediate labor issues that must be regulated are industrial relations which are more friendship / partnership than static, employing costs that depend more on agreement, level of expertise and work results, employee competency development and worker protection to termination of employment that has a tendency to occur on a large scale. The revision of Law No. 13 of 2003 must be able to specifically accommodate the changes occurring in the field of Employment in line with the Industrial Revolution 4.0.
\end{abstract}

Keywords: Labor Law Analysis; Industrial Revolution 4.0; Normative Juridical Method 


\section{PENDAHULUAN}

Pekembangan teknologi informasi yang sangat cepat membawa perubahan yang signifikan bagi dunia industri dan akan berdampak juga pada perubahan hubungan kerja. Hubungan kerja yang bersifat tetap banyak tergantikan dengan pekerja lepas/freelancer, fenomena ini dikenal dengan istilah "GIG Economy". Dalam UU Ketenagakerjaan No 3 Tahun 2013 Pasal 56 ayat 1 dikenal dua bentuk perjanjian kerja yaitu Perjanjian Kerja Waktu Tidak Tertentu (PKWTT) dan Perjanjian Kerja Waktu Tertentu (PKWT) yang merupakan perjanjian kerja freelance untuk berbagai perusahaan. Di Indonesia sudah mulai terlihat fenomena $G I G$ Economy telah terjadi, pada awalnya terlihat jelas pada industri transportasi online dan pekerja yang memiliki keahlian tertentu. GIG Economy mulai berkembang juga pada industri kreatif dan start-up.

Fenomena lain yang muncul di era digital informasi adalah on-demand workers, istilah yang digunakan bagi pekerja yang bersedia bekerja disaat dibutuhkan saja. On-demand workers tidak hanya berkembangan di perusahaan start-up saja, tetapi juga sudah mulai diminati oleh perusahan besar karena dianggap lebih menguntungkan dari segi finansial dan inovasi ketika perusahaan menggunakan tenaga kerja freelancer karena dianggap lebih memiliki ide-ide segar dan baru.

Berkembangnya fenomena " $G I G$ Economy" dan "On-demand worker" di era digital selain membawa dampak positif bagi dunia industri, tetapi dapat menimbulkan berbagai masalah berkaitan dengan hukum ketenagakerjaan. UU nomor 3 tahun 2013 Pasal 1 ayat 15 menyatakan hubungan kerja adalah hubungan antara pengusaha dengan pekerja/buruh berdasarkan perjanjian kerja, yang mempunyai unsur pekerjaan, upah, dan perintah (Budiono, 2012). Perubahan dalam pola hubungan kerja dan sistem pengupahan di era digital yang belum diadopsi dalam UU Ketenagakerjaan Indonesia seperti hubungan kemitraan, berpotensi menimbulkan berbagai permasalahan berkaitan dengan perlindungan hukum terhadap tenaga kerja di Indonesia. Perlu ada pendekatan yang realistis untuk menghadapi digitalisasi kerja yang dapat berpotensi mengeksploitasi tenaga kerja dengan status hukum yang kabur dan upah yang sangat rendah (Santosuosso et al., 2015).
Pandangan optimistik terhadap dampak Gig Economy menekankan bahwa kerja gig dapat meningkatkan produktivitas dan fleksibilitas kerja dan kemampuan untuk menabung (The Emergence of the Gig Economy, 2016). Selain juga sebagai agen bebas (free agent) yang mampu memanfaatkan berbagai pekerjaan dan waktu kerja yang sesuai sehingga mampu melampaui pendapatan pekerja yang hanya bekerja di satu institusi secara permanen (Hill, 2016). Pandangan pesimistik yang melekatkan kerja gig dengan ketidakpastian kerja, ketidaksetaraan ekonomi, kehilangan kerja, dan absennya jaminan sosial (Stewart \& Stanford, 2017). Dalam isu regulasi dan perlindungan hukum pekerja gig, beberapa peneliti menekankan problem relasi kerja yang membuat para tenaga kerja jarak jauh tersebut rendah secara ekonomi dengan sistem subkontraktor dan skema outsourcing yang memperendah kesejahteraan dan jaminan sosial mereka dengan status legal yang kabur dan absennya upah minimun (Bridges, 2017; Campbell \& Burgess, 2018; Stewart \& Stanford, 2017)

Keterbatasan tingkat kompetensi tenaga kerja Indonesia, akan menimbulkan kesulitan untuk bertahan menghadapi tuntutan keahlian yang dibutuhkan industri di era digital ekonomi. Pada tahun 2017 dari 115 juta pekerja Indonesia baru $8 \%$ yang bergelar Sarjana (BPS, 2017). Kebutuhan higher cognitive skills dan technological skills diperkirakan akan meningkat masing-masing sebesar 8\% dan 55\% pada tahun 2030 dibandingkan tahun 2016 (McKinsey Global Institute, 2018). Perubahan komposisi dan keterampilan tenaga kerja memberikan tantangan bagi pemerintah untuk menangani banyak tenaga kerja yang kehilangan pekerjaan dan pelatihan ulang pekerja. Kerja gig menunjukkan ketidakstabilan kerja di tengah pasar tenaga kerja reguler yang terbatas bagi generasi muda berpendidikan sehingga membutuhkan peran negara untuk meningkatkan keterampilan dan peluang kerja (Ruyter, Alex, Brown, \& Burgess, 2019).

Dengan adanya GAP antara supply dan demand berkaitan dengan skill pekerja Indonesia, mengakibatkan terjadinya Pemutusan Hubungan Kerja (PHK) besar-besaran akibat digitalisasi atau otomatisasi. Pemerintah Indonesia harus menyiapkan payung hukum untuk perlindungan bagi pekerja dalam rangka memperoleh kesempatan untuk meningkatkan kompetensi sehingga dapat terhindar dari PHK. 
Berdasarkan putusan atas uji materi pasal 164 ayat 3 UU no 3 tahun 2013 oleh Mahkamah Konstitusi, Pengusaha boleh memilih jalan PHK bila tutup secara permanen (Kemenhumkam, 2017). Bila tidak dapat dihindari terjadi PHK, pemerintahpun harus menjamin pekerja yang terkena PHK mendapat hak-haknya secara layak.

Dampak dari otomatisasi di era revolusi industri 4.0 diprediksi akan mengakibatkan hilangnya $3-14 \%$ profesi pada tahun 2030, tiga puluh $\%$ tugas dari dua pertiga jenis pekerjaan akan dapat digantikan oleh teknologi sperti robot atau kecerdasan buatan (McKinsey Global Institute, 2017). Pekerjaan-pekerjaan yang dapat diotomatisasi akan hilang secara perlahan, tapi jenis-jenis profesi baru akan lahir. Misalnya, lapangan kerja baru muncul di bidang yang berhubungan dengan perancangan dan pengoperasian teknologi itu sendiri, seperti computer programmer dan user interface designer (Siantoro, 2018).

Tidak semua negara di dunia mengalami pola transisi lapangan kerja yang sama. Transisi di negara-negara dengan pendapatan lebih rendah cenderung tertinggal dibandingkan dengan negara-negara lain berpendapatan lebih tinggi. Bahkan, di negara-negara berpendapatan paling rendah hingga kini belum menunjukkan adanya transisi di sektor-sektor lapangan kerja.

Memasuki era industri 4.0 memaksa manusia memasuki dua dunia, yaitu dunia riil dan dunia virtual. Internet of things yang merupakan ruh di era ini mengkondisikan manusia secara personal dan komunal sangat bergantung kepada dunia virtual, yang semakin hari semakin complicated dan smart. Terdapat beberapa jenis pekerjaan yang akan hilang karena digantikan oleh robot atau otomatisasi seperti terlihat pada gambar 1, tetapi juga akan tetap ada bidang pekerjaan yang tidak tergantikan oleh mesin di masa depan seperti tenaga ahli di bidang teknologi informasi, guru, dokter hingga arsitek ("Akankah pekerjaan manusia tergantikan di era revolusi industri $4.0 ?, " 2019)$.

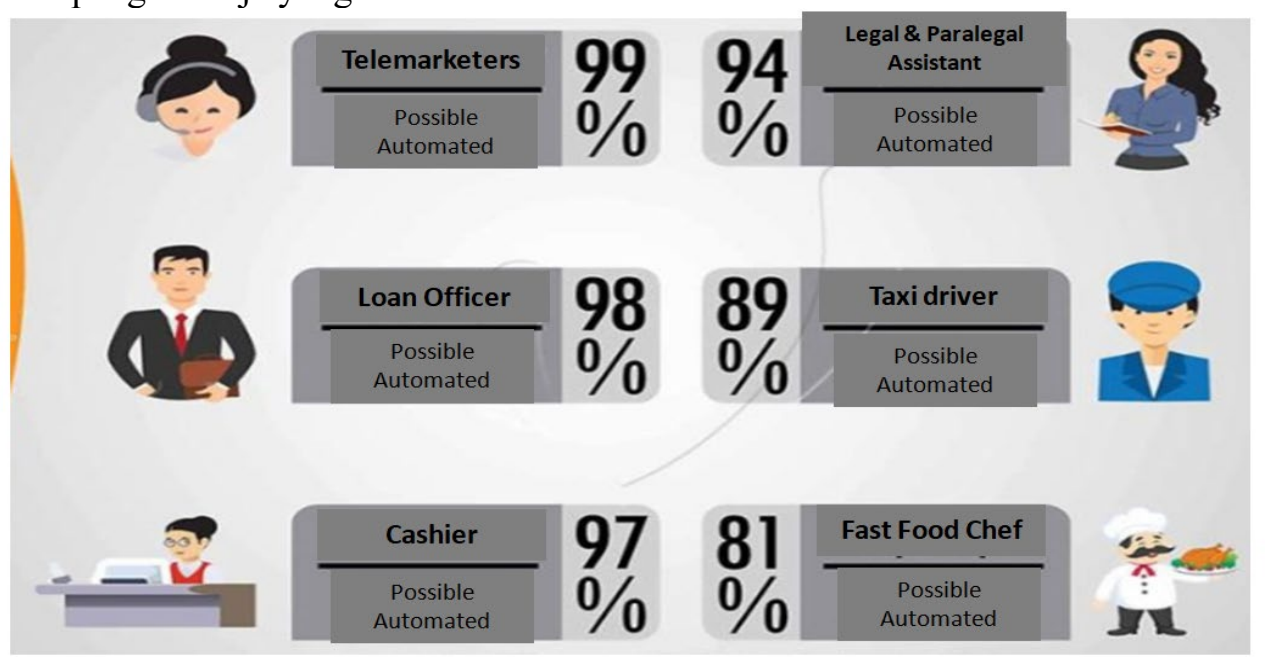

Gambar 1: Jenis Pekerjaan yang Diprediksi Hilang di Era Otomatisasi

Sumber: Frey \& Michael, 2017

Tidak semua negara di dunia mengalami pola transisi lapangan kerja yang sama. Transisi di negara-negara dengan pendapatan lebih rendah cenderung tertinggal dibandingkan dengan negara-negara lain berpendapatan lebih tinggi. Bahkan, di negara-negara berpendapatan paling rendah hingga kini belum menunjukkan adanya transisi di sektor-sektor lapangan kerja.Pola transisi lapangan kerja di Indonesia terbilang berada di level pendapatan "menengah-menengah". Transisi lapangan kerja sudah terjadi pada tahun 2007 atau sembilan tahun lebih dulu dibandingkan negara-negara berpendapatan menengah-bawah, meskipun terlambat tujuh tahun dibandingkan negaranegara berpendapatan menengah-atas. Sebelum 2007, sektor agraris merajai proporsi pekerja di Indonesia. Setelah itu, sektor jasa menggantikan sektor agraris sebagai bidang pekerjaan terbesar. Sementara, tren pekerja sektor industri manufaktur meningkat tipis seperti terlihat pada gambar 2 (Siantoro, 2018). 


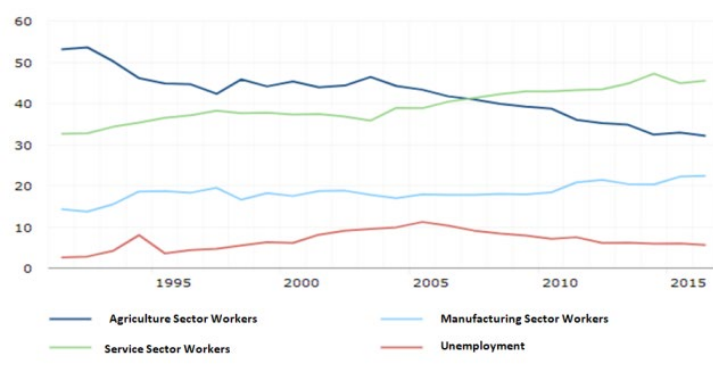

Gambar 2: Perkembangan Pekerjaan di Indonesia

Sumber: Siantoro, 2018

UU Ketenagakerjaan Nomor 3 tahun 2013 disusun sebelum era digital ekonomi berkembang di Indonesia. Dengan adanya berbagai jenis pekerjaan baru, yang dapat merubah bentuk hubungan kerja, mengakibatkan UU Nomor 3 tahun 2013 belum dapat mengakomodir berbagai bentuk perlindungan pekerja di era revolusi industri 4.0. Perlu dilakukan analisis terhadap UU Ketenagakerjaan sejauh mana dapat mengakomodir permasalahan ketenagakerjaan di era Revolusi Industri 4.0 sehingga dapat dilakukan revisi untuk dapat memberikan perlindungan yang maksimal terhadap pekerja Indonesia.

\section{METODE PENELITIAN}

Penyusunan tulisan ini dilakukan dengan menggunakan metode yuridis normatif berupa pendekatan peraturan perundang-undangan. Penulis menggunakan metode penelitian sosiolegal, yaitu mengkaji dinamika hukum dan perundangan-undangan dalam konteks sosiohistorisnya. Penulis pengkaji perundangundangan Ketenagakerjaan di Indonesia seputar relasi kerja, perlindungan tenaga kerja, upah, peningkatan kompetensi tenaga kerja. Pengumpulan data primer diperoleh melalui Forum Group Discusion (FGD) dengan Informan Kunci sebagai pihak-pihak yang berkepentingan yaitu dari sisi pemerintah, industri, serikat pekerja dan pekerja.

\section{HASIL DAN PEMBAHASAN}

\section{A. Kondisi Ketenagakerjaan Indonesia di Era Digital}

Di era digital struktural ketenagakerjaan di Indonesia akan mengalami transformasi. Indonesia akan mengalami beberapa kendala dalam proses transformasi struktural ketenagakerjaan Indonesia (Van, Jan, \& Daan, 2012) di antaranya; pendidikan rendah membuat rendahnya pemanfaatan teknologi, pembangunan yang tidak merata membuat transformasi struktural hanya terjadi di daerahdaerah yang memiliki infrastruktur memadai, fokus ekspor barang mentah di masa lalu membuat industri indonesia telat untuk didorong memproduksi barang- barang dengan nilai tambah yang tinggi.

Transformasi struktur pasar tenaga kerja lebih ke arah sektor jasa dengan produktivitas rendah. Kesempatan kerja di sektor jasa yang besar merupakan salah satu faktor pendorong utama dalam pengurangan kemiskinan. Tetapi, sebagian besar kesempatan kerja di sektor jasa yang tercipta memiliki produktivitas rendah, dengan laju pertumbuhan yang lebih rendah dari rata--rata atau negatif.Dalam 10 tahun terakhir, lapangan kerja baru yang tercipta 23 juta, 21,7 juta di antaranya terserap di sektor jasa. Sektor industri menyerap 3,7 juta dan sektor pertanian berkurang 2,4 juta. Transformasi pasar kerja di Indonesia dapat dilihat pada gambar 3.
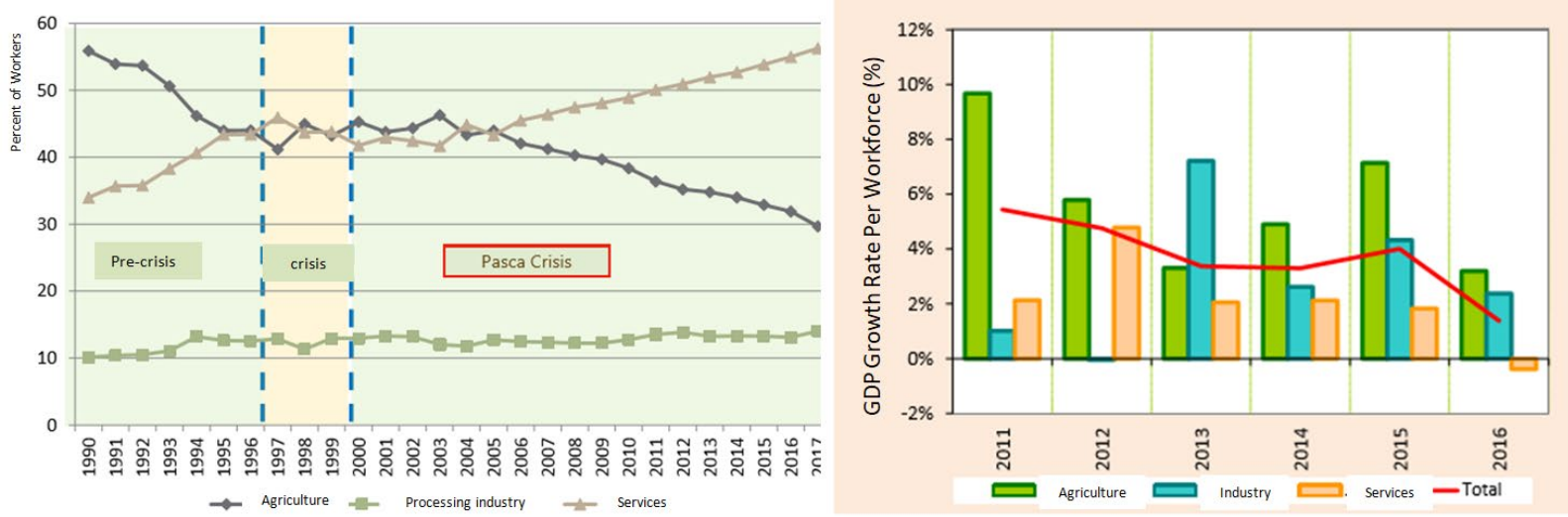

Gambar 3: Transformasi Struktural Pasar Tenaga Kerja di Indonesia

Sumber: Bappenas, 2017 
Sektor jasa terbukti mampu menyerap tenaga kerja formal yang ditunjukkan oleh tren meningkatnya pertambahan tenaga kerja formal di sektor jasa seperti terlihat pada gambar 4 . Tingginya proporsi pekerja formal sektor jasa ini diindikasikan terjadi akibat pesatnya

Additional Workers Based on Formal \& Informal Status

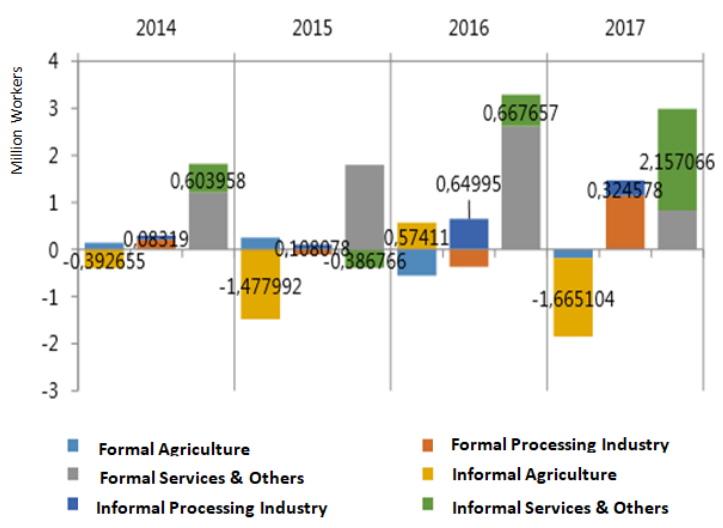

perkembangan ekonomi digital yang mampu menyediakan alternatif lapangan kerja formal, seperti jasa kurir dan angkutan online serta jasa perdagangan. Pembuktian indikasi ini masih memerlukan telaah lebih lanjut dengan menggunakan data Sakernas yang lebih detail.

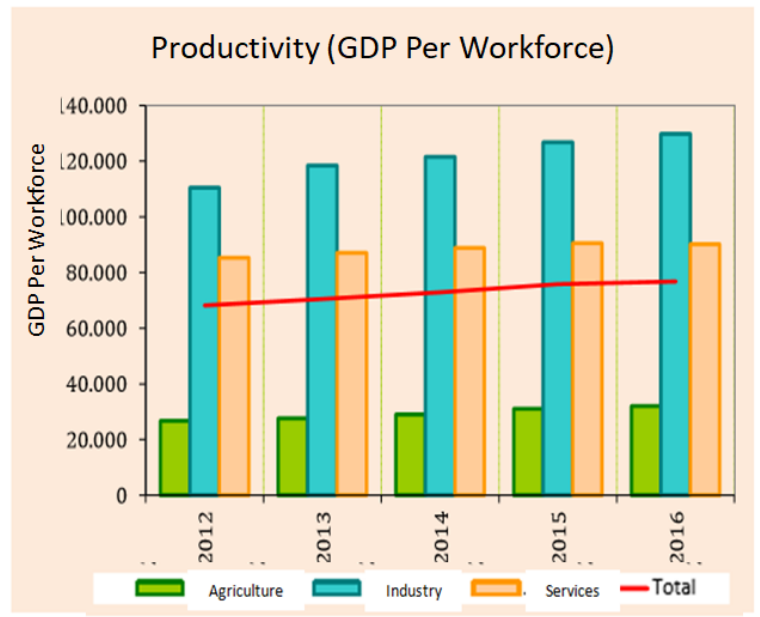

\section{Gambar 4 : Profil Tenaga Kerja Indonesia}

Sumber: Sakernas 2017

Berdasarkan survei Michael Page (perusahaan konsultan perekrutan tenaga kerja professional) yang dilakukan dari sejak Maret 2016-April 2017, dinyatakan bahwa terjadi peningkatan permintaan untuk tenaga bidang IT atau digital sebesar $60 \%$. Mayoritas penduduk Indonesia telah menggunakan internet dan jumlahnya terus meningkat setiap tahunnya. Pasar digital akan naik mencapai $40,5 \%$ atau USD \$81 M dari pasar di Indonesia. Dengan
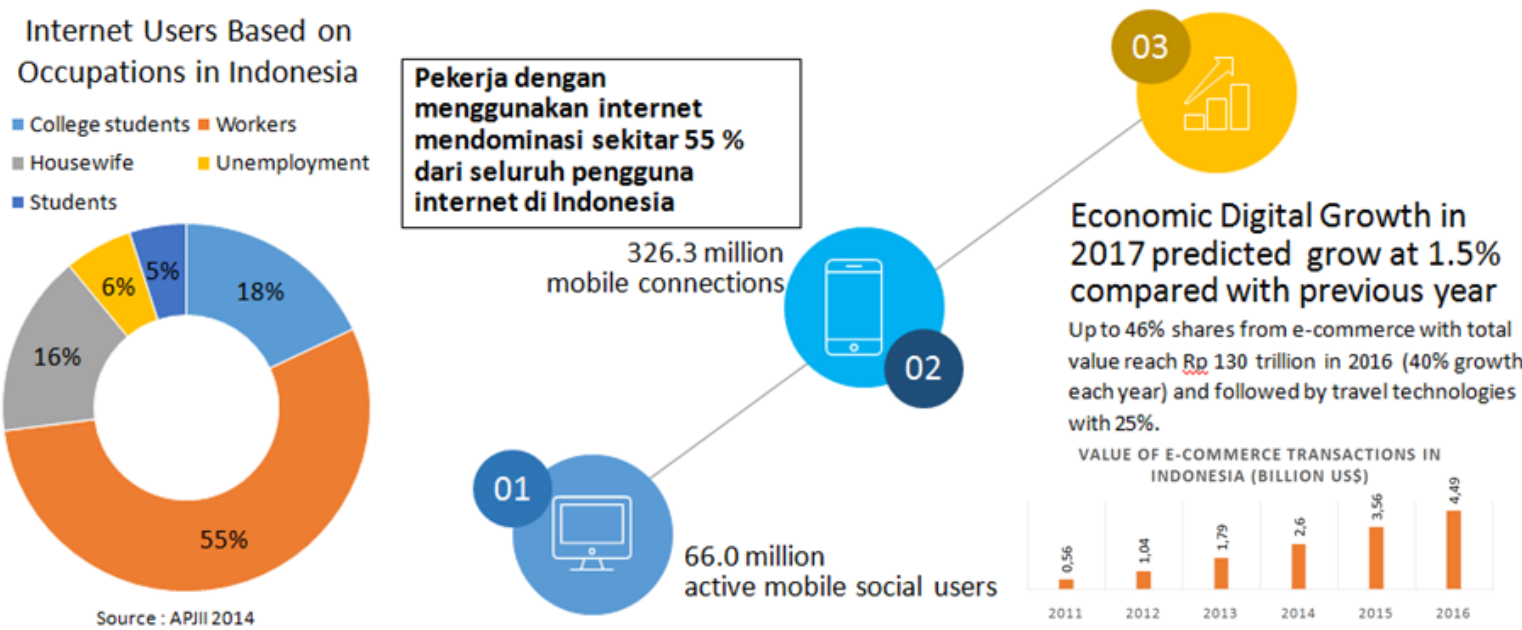

Gambar 5 : Potret Ekonomi Digital Di Indonesia

Sumber: Yasar, 2017

Menurut Penelitian Mckinsey Global Institute (2017) sepertiga aktivitas pekerjaan estimasi USD \$46 M, Sektor e-commerce akan berkontribusi banyak di Indonesia (Yasar, 2017). Gambaran perkembangan penggunaan internet di Indonesia dapat dilihat pada gambar 5 Peningkatan penggunaan internet mengindikasikan terbukanya peluang industri baru dan peluang pekerjaan baru dengan keahlian khusus. diotomatisasi. Demikian juga dengan aktivitas 
pekerjaan di Indonesia $51,8 \%$ dapat diotomatisasi. Menurut penelitian McKinsey (2017), terdapat beberapa pekerjaan (okupasi) di negara berkembang yang akan tumbuh pesat dalam beberapa tahun kedepan yaitu; Pekerjaan yang berkait dengan customer dan membutuhkan interaksi, Care provider sebagai konsekuensi semakin meningkatnya jumlah penduduk lansia, Builder, Pendidik. Skills yang dibutuhkan ke depan berupa penerapan expertis, keahlian berinteraksi, manajemen orang (Manyika et al., 2017). Yang harus dipersiapkan pemerintah Indonesia dalam menghadapi trasnformasi struktural tenaga kerja salah satunya yaitu regulasi berkaitan dengan ketenagakerjaan. Akibat kekosongan hukum sering kali bisnis berbasis digital sulit untuk menentukan dari segi pajak, proteksi terhadap karyawannya, serta hubungan kerja di tengah dunia internasional mengkampanyekan "better work". Kecenderungan regulasi mengarah ke bagaimana menjembatani hak dan martabat karyawan dan kepentingan pengusaha (Santosuosso et al., 2015).

\section{B. Hubungan Industrial Menurut Undang- Undang Ketenagkerjaan Indonesia}

Hubungan kerja yang makin abstrak memerlukan perubahan konsep hubungan industrial saat ini. Dengan munculnya banyak pekerja independen (tanpa majikan), diperlukan penyesuaian terhadap Undang-Undang No.13 Tahun 2003 tentang Ketenagakerjaan. Dalam UU Ketenagakerjaan disebutkan suatu hubungan kerja terjadi karena adanya perjanjian kerja antara pengusaha dan pekerja/buruh. Suatu hubungan kerja harus memiliki tiga unsur yaitu; pekerjaan, upah dan perintah. Status hubungan kerja menurut UU 13 tahun 2003 ada dua jenis yaitu Perjanjian Kerja Waktu Tertentu (PKWT) dan Perjanjian Kerja Waktu Tidak Tertentu (PKWTT). Di era digital akan merubah bisnis model dan management perusahaan. Di masa yang akan datang, khususnya hubungan kerja akan lebih fleksibel dan akan berpengaruh terhadap status pekerja. Hubungan antara pekerja dengan pengusaha tidak hanya sebatas PKWT dan PKWTT tetapi juga bisa berbentuk part time atau hubungan kerja berdasarkan satuan hasil. Walaupun di bidang-bidang tertentu seperti di departemen produksi, deadline, kehadiran di tempat kerja dan rencana shift akan tetap diperlukan di masa depan, dalam bidang ini sangat penting berada di lokasi bisnis.

Beberapa negara seperti Jepang, Korea Selatan, Amerika sudah menerapkan proteksi yang lebih besar bagi pekerja yang tidak tetap atau part timer, sehingga setelah berhenti bekerja mereka sudah aman, disamping itu pemerintah memberikan kebijakan dalam bentuk "unemployment benefit" selama 3-6 bulan selama menunggu memperoleh pekerjaan baru. Dalam kondisi seperti itu status PKWT dan PKWTT tidak masalah karena benefit dan social security pekerja terjamin. Pemerintah perlu segera menyediakan regulasi yang mampu beradaptasi dengan perkembangan teknologi di era digital, khususnya regulasi berkaitan hubungan kerja antara pekerja dan pengusaha, seperti regulasi sistem kontrak, pemberian benefit, dan labor security.

Di era revolusi industri 4.0 akan terjadi perubahan terhadap pola hubungan kerja. Potensi perubahan hubungan kerja di era industri 4.0 dapat dilihat pada gambar 6. Pola hubungan industrial di era revolusi industri 4.0 akan berbeda-beda sesuai dengan sifat dari pekerjaannya. Pola hubungan kerja di sektor konstruksi pada umumnya berdasarkan job supply (borongan mandor), dimana pelaksanaan pekerjaan seperti pemborongan, akan tetapi dilakukan oleh individu-individu. Bahkan terkadang ada pekerja/buruh yang meminta kontrak kerja langsung kepada perusahaan. Di sektor transportasi logistik Hubungan kerja yang diterapkan menggunakan pola PKWT, "semi PKWT" dan pola kemitraan sesuai dengan jenis usaha pengakutan yang dijalankan. Pola PKWT sebagaimana yang diatur di UU 13/2003 sulit diterapkan pada sektor transportasi logistic logistik. Hubungan kerja pada usaha transportasi taksi dan transportasi logistik menggunakan pola kemitraan dan sistem ritase. Selain itu, ada pula yang menggunakan sistem komisi kehadiran ketika pekerja "standby". Pola kemitraan bersifat bussines to bussines sehingga mengunakan pendekatan hukum perdata murni. Hubungan kerja pada usaha perhotelan dan restauran umumnya menggunakan sistem kontrak kerja, seperti bagian security, cleaning service dan laundry. 


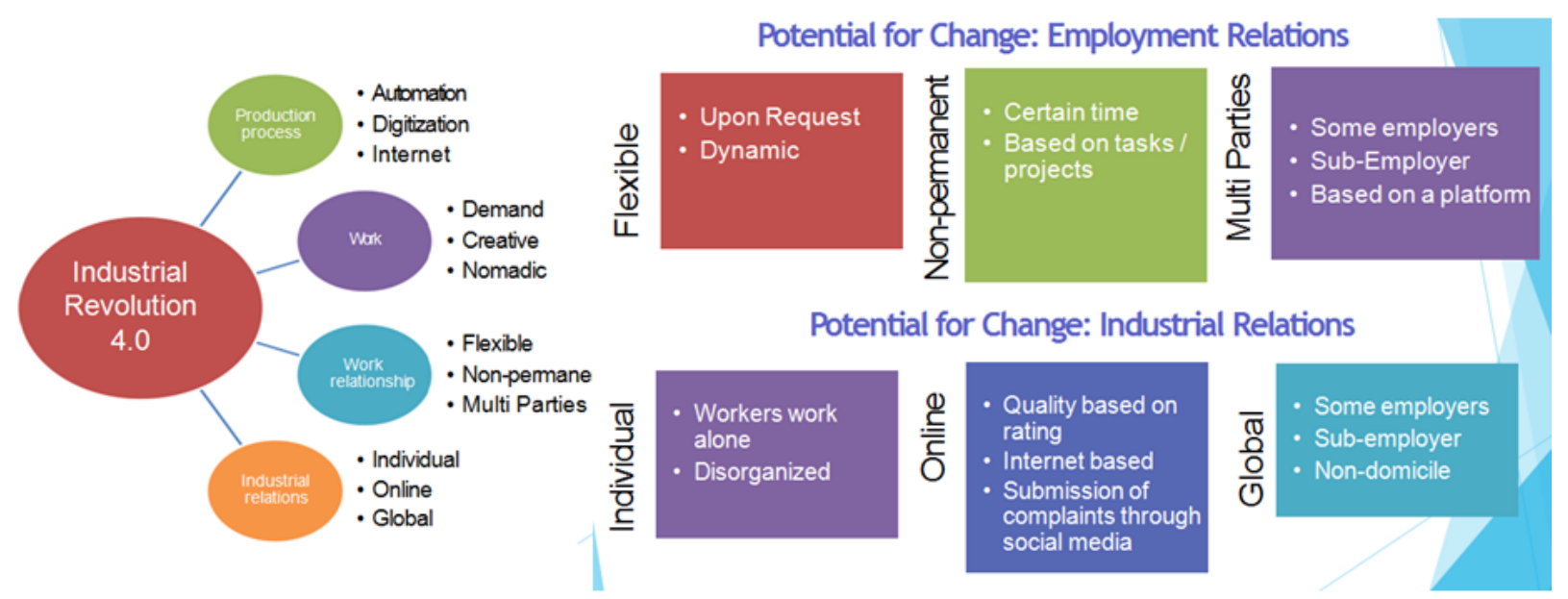

Gambar 6 : Potensi Perubahan Pekerjaan dalam Revolusi Industri 4.0

Sumber: Widianawati, 2019

Sistem kerja di era gig economy pada umumnya masih didukung oleh regulasi ketenagakerjaan yang ambigu dan ketinggalan zaman (dalam hal konsep kerja, relasi kerja, dan tempat kerja), tidak memadainya penegakan hukum ketenagakerjaan, mengakibatkan posisi pekerja gig misalnya sebagai kontraktor independen (independent contractor) terdiskualifikasi dari standar proteksi tenaga kerja, dari mulai upah, keselamatan kerja, dan jaminan sosial, negosiasi antar pemanggu kepentingan menjadi sangat penting (Ruyter et al., 2019). UU Ketenagakerjaan di Indonesia perlu disesuaikan sehingga dapat menyediakan perlindungan yang maksimal kepada pekerja dan pengusaha di era industri 4.0, beberapa perubahan yang dapat dilakukan antara lain;

1. Hubungan kerja masih dapat di dasarkan pada PKWT/PKWTT tetapi dibutuhkan skema perlindungan untuk kedua jenis hubungan kerja tersebut. Dunia kerja ke depan lebih ke arah pekerja tidak tetap, UU Ketenagakerjaan harus dapat memberikan keamanan, perlindungan dan kenyamanan bagi pekerja yang tidak tetap.Apapun jenis hubungan kerjanya, semuanya harus terlindungi baik pekerja tetap maupun pekerja tidak tetap seperti yang banyak diterapkan di negara maju. Ketika hubungan kerja berakhir harus tetap memperoleh manfaat baik untuk pekerja yang tetap maupun yang tidak tetap, sehingga ketika mau berpindah pekerja tidak ada lagi kekhawatiran.

2. Perjanjian Kerja Waktu Tertentu (PKWT) sebagaimana disebutkan dan diatur di dalam Pasal 56 ayat (1) dan (2) UU
Ketenagakerjaan didasarkan pada jangka waktu dan selesainya suatu pekerjaan tertentu. PKWT dijalankan selama 1 tahun, kemudian diperpanjang lagi 1 tahun dan ketika memasuki tahun ketiga, pekerja dievaluasi sebagai dasar pertimbangan untuk diangkat menjadi pekerja PKWTT. UU Ketenagakerjaan harus lebih memberi keleluasan dalam mengatur jangka waktu PKWT berdasarkan kesepakatan antara pengusaha dan buruh serta harus diimbangi dengan peningkatan perlindungan bagi pekerja pada saat berakhirnya PKWT. Hal ini diwujudkan dengan mewajibkan pengusaha memberikan kompensasi kepada pekerja/buruh pada saat berakhirnya PKWT.

3. KEPMEN No. 100 Tahun 2004 merupakan peraturan pelaksanaan dari UU Ketenagakerjaan berkaitan dengan PKWT, yang di dalamnya mengatur juga mengenai Perjanjian Kerja Harian Lepas. Dengan demikian, Perjanjian Kerja Harian Lepas menurut KEPMEN ini merupakan bagian dari PKWT yang dilaksanakan untuk pekerjaan-pekerjaan tertentu yang berubahubah dalam hal waktu dan volume pekerjaan serta upah didasarkan pada kehadiran. Perjanjian kerja harian lepas dilakukan dengan ketentuan pekerja/buruh bekerja kurang dari 21 (dua puluh satu) hari dalam 1 (satu) bulan. Pekerja Harian Lepas juga berhak mendapatkan jaminan sosial ketenagakerjaan sebagaimana yang diatur dalam Undang-Undang Nomor 24 tahun 2011 tentang Badan Penyelenggara Jaminan Sosial(Satria, Aryani, \& Mudana, 2014). 
4. Hubungan kerja yang banyak terjadi di era digital adalah hubungan kerja yang lebih bersifat kemitraan, bagi hasil (profit sharing), hubungan korporasi (corporate agreement in article of incorporation) dll, seperti pada sektor transportasi online, Pedagang (roti) keliling, sistem kontrak pekerjaan. Diperlukan Perlindungan Khusus terhadap pekerja yang terpengaruh oleh ketidakpastian keberadaan hubungan kerja, di era digital yang belum diatur secara khusus di dalam UU No No.13 Tahun 2003 tentang Ketenagakerjaan. Walaupun belum diatur secara khusus tetapi didalam KUH Perdata Pasar $1601 \mathrm{BW}$ telah disebutkan "Jika suatu perjanjian mengandung tanda2 (unsur-unsur) suatu perjanjian perburuhan (:perjanjian kerja) -Di Dalam Hubungan Kerja (DHK)-, beserta tanda perjanjian jenis lain Di Luar Hubungan Kerja, maka berlakukah -baikketentuan perihal perjanjian kerja- maupun ketentuan perihal perjanjian lain (DHK tersebut) yang tanda-tandanya ikut terkandung di dalamnya itu; Jika ada pertentangan diantara -kedua- ketentuan ini (tersebut), maka berlakukan ketentuan perihal perjanjian kerja [Pasal 1601 supra 1
BW]. Maksudnya, apabila ada perjanjian yang ada unsur-unsur hubungan kerja, tetapi ada juga unsur-unsur hubungan hukum lainnya -selain hubungan kerja-, maka yang diberlakukan adalah ketentuan-ketentuan mengenai hubungan kerja.

\section{Pengupahan Menurut Undang-Undang Ketenagakerjaan di Indonesia dan Penyesuaiannya di Era Digital}

Dalam sistem pengupahan di Indonesia digunakan konsep upah minimum yang dimaksudkan sebagai jaring pengaman serta menjamin tidak ada pekerja miskin. Upah minimum merupakan upah terendah yang ada dalam perekonomian. Dengan adanya upah minimum diharapkan dapat melindungi pekerja dari eksploitasi di pasar kerja yang biasanya dialami ketika terjadi surplus tenaga kerja seperti di Indonesia. Upah minimum ditetapkan untuk memastikan pekerja dapat memenuhi kebutuhan hidup sehari-hari. Kebijakan pengupahan di Indonesia mengalami banyak perubahan seperti terlihat dalam gambar 7 berikut :

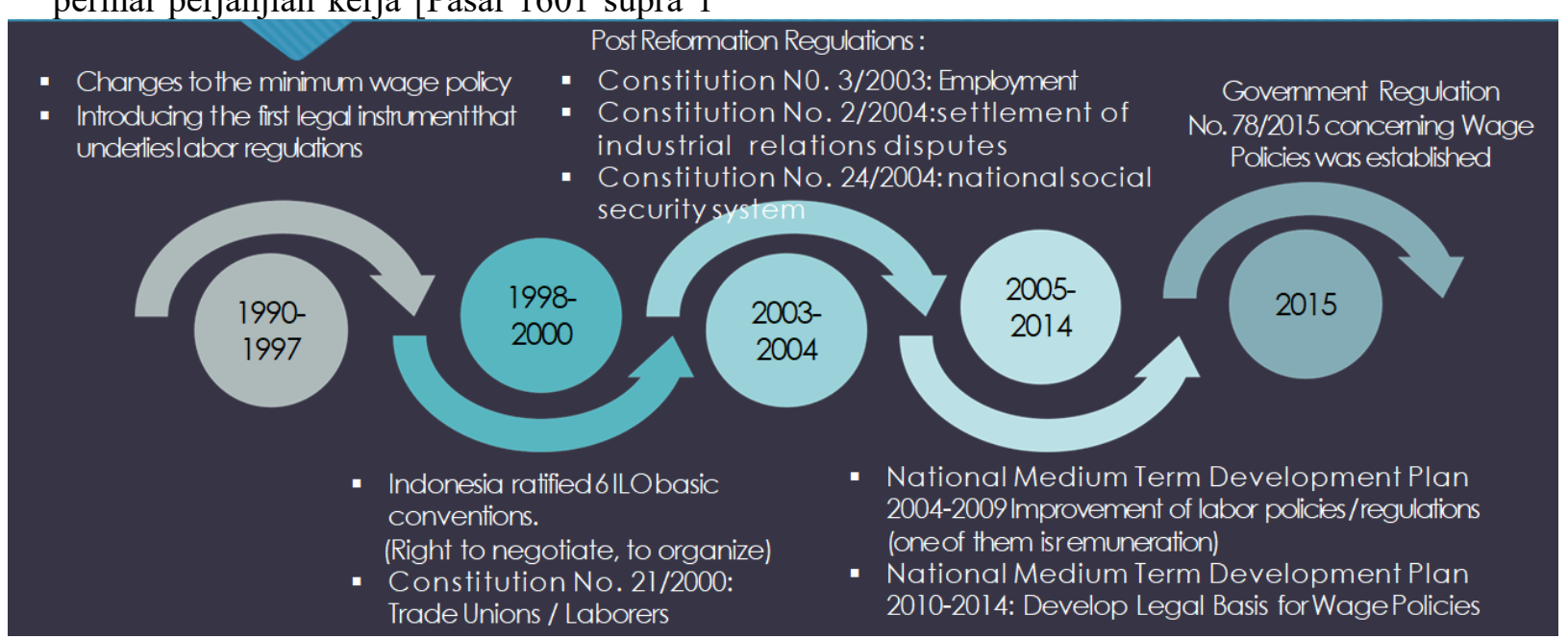

Gambar 7 : Tinjauan Umum tentang Kebijakan Ketenagakerjaan Mengenai Sistem Upah di Indonesia

Sumber : Iryanti, 2018

Berdasarkan Peraturan Pemerintah (PP) 78/2015 penetapan formula upah minimum bertujuan untuk memastikan besaran peningkat upah minimum sudah mengakomodir dua kepentingan pekerja dan pengusaha. Upah minimum bertujuan untuk menyalurkan pendapatan pada kelompok pekerja sehingga dapat memenuhi kebutuhan hidup sehari-hari. Perubahan upah minimum harus mengikuti perubahan produktivitas pekerja dan produktivitas perusahaan.

Ketika Indonesia mulai memasuki tren pasar kerja dalam era digital, kebijakan sistem pengupahan tentunya perlu disesuaikan. Kebijakan pengupahan harus disesuaikan dengan pasar kerja di era digital yang lebih kompetitif. Yang menjadi bahan pertimbangan utama dalam menentapkan kebijakan 
pengupahan di era digital adalah Produktivitas dan Daya Saing. Selain itu dengan mengembangkan sistem kerja yang lebih fleksibel,sistem pengupahan di Indonesia bisa diberikan berupa upah harian atau upah per jam. Upah yang didapat bukan hanya berdasarkan bulanan melainkan pekerja dapat memilih atas satuan hasil, per hour, per project. Selama ini upah ditetapkan sebagai upah per bulan, kenyataannya di era pasar kerja fleksibel tidak selalu bisa berdasarkan upah bulanan. Perlu pengkajian mendalam terhadap sistem upah berdasarkan satuan hasil sebagaimana yang diatur dalam PP 78/2015. Upaya yang dapat dilakukan untuk mencegah terjadinya berbagai konflik antara pekerja dan pengusaha terkait sistem pengupahan adalah dengan meningkatkan fungsi mekanisme pengupahan melalui perundingan kolektif dan perjanjian kerja bersama sebagai sarana perundingan upah. Terdapat 2 bentuk perundingan upah yang dapat dilakukan seperti terlihat pada gambar 8 .

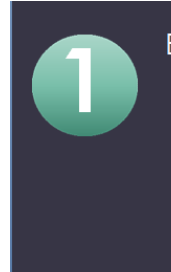

Encourage Collective bargaining and

Collective Labor Agreements at the

companylevel (such as codes on acting in good faith)

Improve Collective Labor Agreements (PKB) which currently only cover a minority of workers

- Avoiding lagging growth in workers' real wages

- Avoiding wage inequality (best practice in some countries: PKB correlates with low inequality)

Gambar 8 : Sistem Negosiasi Kolektif dan Perjanjian Kerja Bersama sebagai Sarana Negosiasi Upah

Sumber: Iryanti, 2018
Individual contract (bipartite negotiation

links wage increases to increases productivity)

Workers and employers can sit in line. $>$ Representation is key.

\section{Pengembangan Kompetensi Pekerja Menurut Undang-Undang \\ Ketenagakerjaan}

Pekerjaan di masa depan akan memerlukan kemampuan teknis yang tinggi (High technical skill) dan oleh karena itu menjadi tugas pemangku kebijakan untuk memastikan para pekerja mendapatkan kemampuan teknis yang diperlukan dan mengurangi dampak sosial hilnyanya hilangnya pekerjaan melalui penerapan regulasi seperti Universal Basic Income (UBI) untuk mengamankan sumber

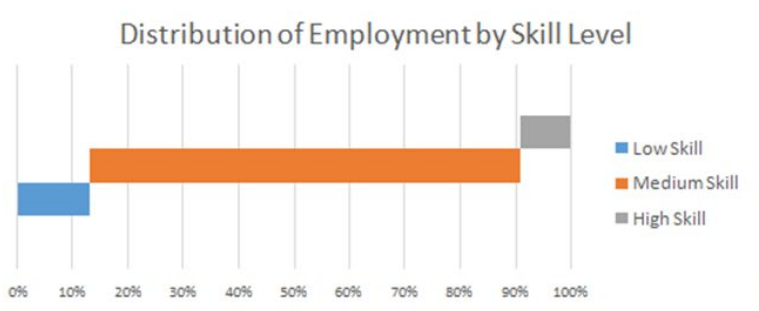

pendapatan bagi mereka yang kehilangan pekerjaan (Stefano, 2019). Bila dilihat dari distribusi pekerja di Indonesia berdasarkan tingkat keahliannya, hanya 9-10\% pekerja yang tergolong high skill (manager, profesional, teknisi) dari total pekerja di Indonesia. Rata-rata $74 \%$ dikategorikan mempunyai medium skill. Demikian pula komposisi tenaga kerja di dominasi oleh pekerja dengan komptensi yang rendah dilihat dari pendidikannya. (hanya lulus sekolah dasar) seperti terlihat pada gambar 9 .

Distribution Employment by Education Level

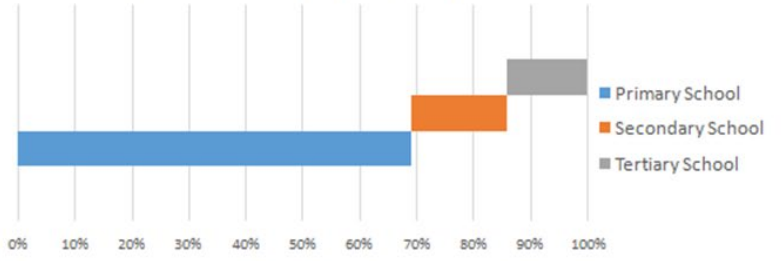

Gambar 9 : Distribusi Tenaga Kerja Indonesia Menurut Tingkat Keahlian dan Tingkat Pendidikan

Sumber : Chang \& Huynh, 2016 
Otomatisasi industri (Padat karyateknologi) adalah tantangan khususnya bagi negara seperti Indonesia yang mana di dominasi oleh pekerja lower level education. Sehingga otomatisasi berdampak pada termination yang besar di Indonesia, 56,2\% dari total pekerja di Indonesia (107,56 juta pekerja) mempunyai resiko yang tinggi terhadap transformasi digital pada dekade selanjutnya seperti terlihat pada gambar 10. Sektor terbesar dari otomatisasi terdapat pada sektor retail dan manufaktur sebesar 91,1 \%.Di Indonesia, pekerja yang hanya lulus sekolah dasar sebanyak $50 \%$ lebih akan mendapatkan potensi resiko yang besar dibandingkan dengan pekerja yang mempunyai pendidikan yang tinggi. Salah satu upaya yang dapat dilakukan adalah Reformasi dalam bidang ketenagakerjaan dengan menyiapkan skill dan kompetensi pekerja sebaik mungkin khususnya pemahaman terhadap teknologi.
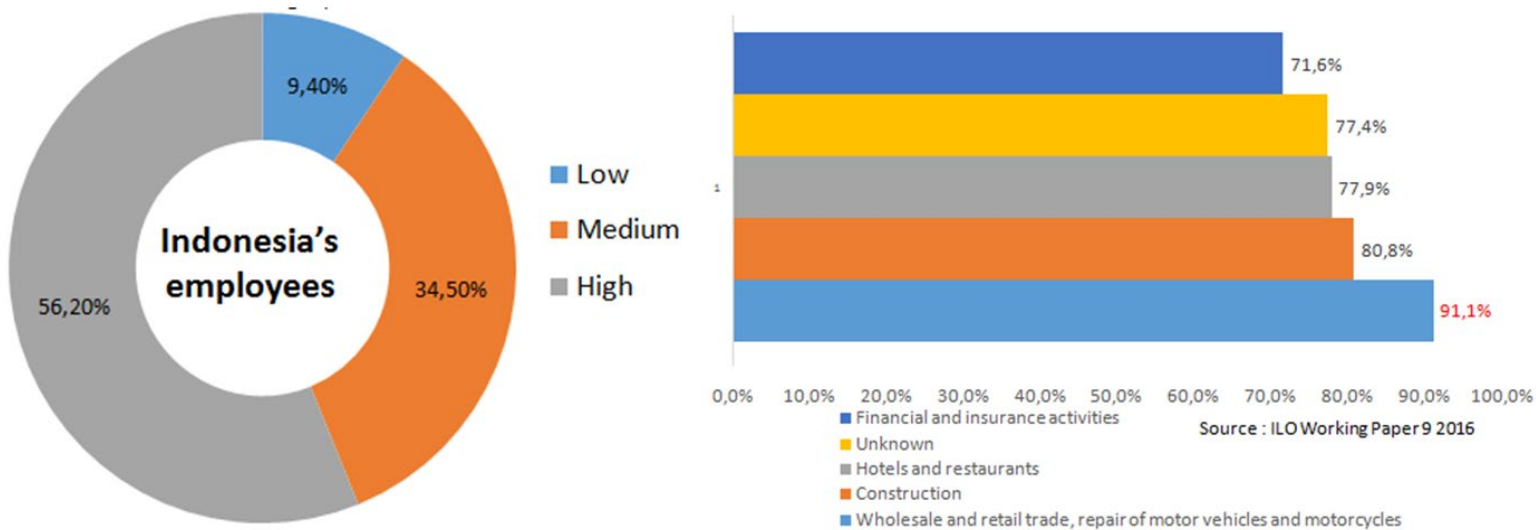
Gambar 10 : Pasar Kerja Di Indonesia $\begin{aligned} & \text { Berdasarkan Sektor Satu Digit Dan Kategori Risiko } \\ & \text { Otomatisasi }\end{aligned}$

Sumber : Chang \& Huynh, 2016

Di dalam UU Ketenagakerjaan terdapat banyak pasal yang mengatur kewajiban perusahaan atau pemilik usaha, untuk meningkatkan dan mengembangkan kompetensi karyawannya melalui pelatihan kerja (Pasal 11, 12 (3), 18 (1), 23). Pelatihan kerja tersebut dapat diadakan melalui sistem pelatihan bersama, dengan pemerintah atau pihak lain sebagai penyedia jasa pelatihan. Salah satu contoh pelatihan yang dapat dilakukan langsung oleh perusahaan adalah magang. Melalui program magang ini, kamu sebagai pekerja akan mampu meningkatkan skill agar sesuai dengan kebutuhan perusahaan. Di samping itu, perusahaan juga akan mendapatkan sumber daya manusia yang berkualitas. Hal ini akan menjadi win win solution bagi kedua pihak. Diperlukan Koordinasi yang efektif antar institusi yang terkait dalam pelaksanaan training pekerja baik yang low skill maupun pekerja dari generasi baby boomer untuk bisa melakukan improvment dan digital adoption.

\section{E. Pemutusan Hubungan Kerja Menurut UU Ketenagakerjaan Indonesia}

Di Indonesia sendiri PHK akibat digitalisasi atau omotomatisasi, masif terjadi di tahun 2018. Kurang lebih 100 ribu pekerja kehilangan pekerjaannya sebagai akibat pergerakan ekonomi digital. Sektor retail, perbankan, transportasi, dan manufaktur khususnya otomotif, teksil, dan elektronik rentan mengalami pemutusan hubungan kerja dikarenakan digitalisasi dan otomatisasi.

Mahkamah konstitusi telah membuat putusan atas uji materi pasal 164 ayat $3 \mathrm{UU}$ nomor 3 tahun 2013 tentang ketenagakerjaan dengan membuat penafsiran yang jelas tentang efisiensi dimana pengusaha hanya boleh mimilih jalan PHK apabila perusahaan tutup secara permanen. Pengertian efisiensi seperti yang tertuang dalam hukum ketenagakerjaan di antaranya melakukan pengurangan upah dan fasilitas pekerja tingkat atas, mengurangi shift kerja, menghilangkan kerja lembur, mengurangi jam kerja, mengurangi hari kerja, dan merumahkan pekerja secara bergilir, tidak memperpanjang kontrak bagi pekerja yang sudah habis masa kontraknya, dan memberikan pensiun bagi yang memenuhi syarat.

Pengusaha tidak bisa lagi terlalu fokus pada peningkatan produksi saja dan mengabaikan program pelatihan dan pengembangan, untuk dapat menghadapi revolusi industri 4.0 dan menghindari PHK secara massal, kedua belah 
pihak baik pekerja dan pengusaha harus dapat merubah pola pikir, pola kerja, dan menyediakan waktu untuk program pelatihan, karena apabila transformasi keterampilan tidak dapat berjalan dengan cepat maka PHK tidak bisa dihindari.

\section{Beberapa}

penyesuaian

UU

Ketenagakerjaan di Indonesia yang diperlukan berkaitan dengan permaslahan PHK adalah sebagai berikut :

1. Bentuk kompesasi PHK yang diberikan uang pesongon dan uang penggantian masa kerja. uang penggantian hak tidak dimasukkan lagi karena sudah ada manfaat lain yang isinya sama

2. Besaran PHK disesuaikan dengan penyebab PHK, tidak bisa disamakan semua tetapi harus disesuaikan dengan alasan pekerja di PHK.

3. Penggabungan kepemilikan perusahaan tidak bisa dikaitkan mengkaitkan dengan PHK

4. Pada saat ini Konsep pesangon diatas kertas ada dan bisa dibayarkan, tetapi kenyataannya hanya $20 \%$ yang mendapatkan pesangon karena terlalu tinggi kalau harus dibayarkan sebesar 32 bulan upah, sehingga tidak realisatis. Perlu dilakukan pengurangan kompensasi pesangon, tidak ditiadakan tetapi dialihkan pada program lain yaitu jaminan sosial berupa jaminan kehilangan pekerjaan (unemployment benefit), jaminan pelatihan sertifikasi. Pekerja lebih besar kemungkinannya untuk mendapatkan manfaat, bisa lebih besar dari pesangon karena ada pengembangan. Tidak semuanya dalam bentuk uang seperti pelatihan dan sertifikasi. Iuran untuk jaminan sosial diupayakan jangan sampai menambah beban pengusaha. Diperlukan restruturisasi dari iuran yang sudah ada menjadi 2 program yang baru.

\section{KESIMPULAN}

Dalam upaya melindungi pekerja di era digital, diperlukan penyesuaian kembali terhadap UU Ketenagakerjaan di Indonesia. Dengan berkembangkan hubungan kerja yang lebih fleksibel di era digital, UU Ketenagakerjaan perlu mengatur kembali jenisjenis hubungan kerja beserta perlindungan sosialnya. Sistem pengupahan di era digital tidak selalu menggunakan sistem bulanan, UU Ketenagakerjaan perlu pengatur sistem pengupahan per jam dan per hari sesuai dengan perkembangan hubungan kerja yang terjadi. Dengan masih rendahnya tingkat pendidikan dan keterampilan tenaga kerja Indonesia, maka pemerintah perlu menyediakan dasar hukum yang kuat untuk menjamin pekerja mendapatkan hak untuk dapat meningkatkan kompetensinya. Peningkatan jaminan sosial bagi pekerja di era digital harus diupayakan tidak menambah beban pagi pengusaha, tetapi lebih diupayakan untuk memperluas manfaat dari jaminan sosial yang sudah ada sehingga lebih realitis dalam pelaksanaannya.

\section{DAFTAR PUSTAKA}

Akankah pekerjaan manusia tergantikan di era revolusi industri 4.0? (2019). Retrieved from https://forumpendidikan.id/revolusiindustri-4-0/

Bappenas. (2017). Transformasi Struktur Tenaga Kerja.

Bridges, L. (2017). Flexible as Freedom? The Dynamics of Creative Industry Work and the Case Study of the Editor in Publishing. New Media and Society, 5.

Brown, \& Ronald, C. (2016). Made in China 2025: Implications of Robotization and Digitalization on M MN Labor Supply Chains and Workers Labor Rights in China. Tsinghua China Law Review, 9, 186-210.

Campbell, I., \& Burgess, J. (2018). Patchy Progress? Two Decades of Research on Precariousness and Precarious Work in Australia. Labour \& Industry, 28(1), 48-67.

Chang, J.-H., \& Huynh, P. (2016). Asean In Transformation The Future of Jobs At Risk Of Outomation.

Frey, C. B., \& Michael, O. (2017). The Future of Employment Carl. In Turkish Journal of Endocrinology and Metabolism.

Hill, A. (2016). When McKinsey Met Uber: The Gig Economy Comes to Consulting. Financial Times.

Iryanti, R. (2018). Platform Untuk Upah Yang Adil dan Kompetitif di Indonesia.

Manyika, J., Lund, S., Chui, M., Bughin, J., Woetze, J., Batra, P., ... Sanghvi, S. (2017). JOBS LOST, JOBS GAINED: WORKFORCE TRANSITIONS IN A TIME OF AUTOMATION. McKinsey Global Institute.

Ruyter, D., Alex, Brown, M., \& Burgess, J. (2019). Gig Work and the Fourth Industrial Revolution: Conceptual and Regulatory 
Challenges. Journal of International Affairs, 1, 37-50.

Santosuosso, A., Goodenough, O. R., \& Tomasi, M. (2015). The Challenge of Innovation in Law: The Impact of Technology and Science on Legal Studies and Practice. Pavia University Press.

Satria, I. W. S. W. G., Aryani, N. N. M., \& Mudana, I. (2014). PERLINDUNGAN HUKUM TERHADAP PEKERJA HARIAN LEPAS DITINJAU DARI PERATURAN PERUNDANGUNDANGAN DI INDONESIA. Kertha Semaya, 2(4).

Siantoro, A. (2018). Analisis Data: Revolusi Industri 4.0 : Peluang Munculnya ProfesiProfesi Baru. Retrieved from https://katadata.co.id/analisisdata/2018/04/ 20/revolusi-industri-40-peluangmunculnya-profesi-profesi-baru

Stefano, V. De. (2019). Negotiating the Algorithm': Automation, Artificial Intelligence and Labour Protectio. Artificial Intelligence and Labour Protecion, 41(1), 1-32.

Stewart, A., \& Stanford, J. (2017). Regulating Work in the Gig Economy: What Are the Options. The Economic and Labour Relations Review, 28(3), 420-437.

The Emergence of the Gig Economy. (2016).

Van, Z., Jan, L., \& Daan, M. (2012). Ekonomi Indonesia 1800-2010: Antara Drama dan Keajaiban Pertumbuhan,. Jakarta: Buku Kompas dan KITLV.

Widianawati, A. (2019). ASPEK DALAM HUBUNGAN KERJA.

Yasar, I. (2017). How Digitalization is Changing Enterprises and Jobs in Indonesia. 